\title{
Flash Pyrolysis of Oleic Acid as a Model Compound Adsorbed on Supported Nickel Catalysts for Biofuel Production
}

\author{
Roger Fréty, ${ }^{a}$ Marilia R. Santos, ${ }^{a}$ Renan F. Sales, ${ }^{a}$ Antonio O. S. Silva, ${ }^{b}$ \\ Celmy B. M. Barbosa ${ }^{a}$ and Jose G. A. Pacheco*,a \\ ${ }^{a}$ Departmento de Engenharia Química, Centro de Tecnologia e Geociências, \\ Universidade Federal de Pernambuco, 50740-521 Recife-PE, Brazil \\ ${ }^{b}$ Departmento de Engenharia Química, Centro de Tecnologia, \\ Universidade Federal de Alagoas, 57072-970 Maceió-AL, Brazil
}

\begin{abstract}
A pirólise rápida do ácido oleico foi estudada sobre catalisadores com $10 \%$ Ni suportados em sílica e alumina. Os catalisadores foram impregnados com $10 \% \mathrm{~m} / \mathrm{m}$ de ácido oleico. Os precursores secos e os catalisadores contendo ácido oleico foram caracterizados por análise termogravimétrica. Os catalisadores calcinados foram analisados por difração de raios X (XRD) e redução à temperatura programada (TPR). As amostras com ácido oleico adsorvido foram submetidos à pirólise rápida a $650{ }^{\circ} \mathrm{C}$. A pirólise de ácido oleico puro levou a $10 \%$ de conversão, enquanto a pirólise catalítica resultou em praticamente completa conversão. O catalisador $\mathrm{NiO}$ /alumina produziu mais hidrocarbonetos do que o $\mathrm{NiO}$ /sílica. Os principais produtos obtidos com $\mathrm{NiO} /$ ś́lica foram 1-alcenos, enquanto que os principais produtos obtidos com $\mathrm{NiO}$ /alumina foram isômeros de alcenos e aromáticos, e pequenas quantidades de compostos oxigenados, principalmente álcoois. A pirólise rápida de ácido oleico adsorvido em catalisadoras representa um método útil para distinguir as propriedades dos catalisadores e suas diferentes atividades.
\end{abstract}

Flash pyrolysis of oleic acid was studied over $10 \mathrm{wt} . \%$ nickel catalysts supported on silica and alumina. The catalysts were impregnated with $10 \mathrm{wt} . \%$ oleic acid. The dried precursors and the catalysts containing oleic acid were characterized by thermogravimetric analysis. The calcined catalysts were analyzed by X-ray diffraction (XRD) and temperature programmed reduction (TPR). Samples containing adsorbed oleic acid were submitted to flash pyrolysis up to $650{ }^{\circ} \mathrm{C}$. Whereas pyrolysis of oleic acid without catalyst converted only about $10 \%$, the pyrolysis of oleic acid adsorbed on catalysts allowed practically a complete conversion. NiO/alumina yielded a higher amount of liquid hydrocarbons than $\mathrm{NiO} /$ silica. The main products obtained with $\mathrm{NiO} /$ silica were 1-alkenes, whereas the main products obtained with $\mathrm{NiO} /$ alumina were alkene isomers and aromatics. Small amounts of oxygenated compounds were also observed, principally alcohols. The flash pyrolysis of oleic acid adsorbed on different catalyst surfaces appears as a useful way to distinguish activity trends of different catalyst samples.

Keywords: flash pyrolysis, biofuel, oleic acid, nickel catalysts

\section{Introduction}

Upgrading of vegetable oils and related compounds to obtain liquid fuels has been extensively studied since the end of the 70's. Two important chemical routes have been used: transesterification and thermochemical processes, these latter either through cracking or hydrocracking. ${ }^{1-6}$

Transesterification is the process usually employed at the industrial level. In this case, vegetable oils react with

*e-mail: jose.pacheco@ufpe.br, geraldo.ufpe@gmail.com a short chain alcohol to form esters of fatty acids. These esters are usually named biodiesel. Industrially, methyl esters of fatty acids can be added to petroleum diesel up to 7-8 wt.\%. These mixtures, unlike pure petroleum diesel, show a slightly lower energetic power due to their oxygen content and they have limited chemical stability. Therefore, stabilizers must be added to biodiesel to render it useful. ${ }^{8,9}$ The thermochemical routes can lead to highly deoxygenated compounds fully miscible with liquid fuels of fossil origin. ${ }^{5}$ Companies, such as UOP LLC, Neste Oil, Petrobras and Eni S. p. A., have studied hydrocracking of 
triglycerides with catalysts similar to the ones used in the hydrotreatment processes. For example, Eni S. p. A. and UOP LLC are using the Ecofining ${ }^{\mathrm{TM}}$ technology to obtain green diesel, a qualitative biofuel..$^{10}$ When carried out in the presence of hydrotreating-type catalysts, at hydrogen pressures higher than $3 \mathrm{MPa}$ and at temperatures between $300-400{ }^{\circ} \mathrm{C}$, hydrocracking of triglycerides leads to important amounts of saturated linear hydrocarbons, with a high selectivity towards C16-C18 molecules. ${ }^{5,11}$ During hydrocracking two main routes have been observed: decarboxylation and decarbonylation (DCO). In both of these reactions the triglycerides are initially transformed into fatty acids that can lose $\mathrm{CO}_{2}$ and $\mathrm{CO}+\mathrm{H}_{2} \mathrm{O}$, producing hydrocarbons which have a carbon chain with one less $\mathrm{C}$ atom than the fatty acid from the initial feed. ${ }^{5} \mathrm{~A}$ third reaction is also observed in the presence of hydrogen and is considered as hydrodeoxygenation (HDO). In this case, oxygen is eliminated from the intermediate fatty acid as $\mathrm{H}_{2} \mathrm{O}$ and the main hydrocarbon molecules formed have the same carbon number as the starting fatty acid chain. ${ }^{5}$ Because the HDO reaction consumes important amounts of hydrogen, studies aiming at favoring DCO over HDO are important. Kubicka and Kaluza ${ }^{12}$ showed that hydrotreating-type catalysts containing only Mo species favor HDO during rapeseed oil hydrocracking, whereas the addition of Ni favors DCO. Kubicka et al. ${ }^{13}$ also showed that Ni-Mo catalysts with the same composition and the same method of preparation have HDO activity varying with the nature of the support. Therefore, modification of the composition of catalysts appears as an effective way to direct hydrocracking of triglycerides towards DCO.

In order to limit hydrogen consumption, cracking of triglycerides and/or model compounds in the absence of added hydrogen has been considered. Cracking without a catalyst leads to a large family of deoxygenated liquid organic compounds, such as alkenes and alkanes, together with oxygenated compounds, such as carboxylic acids, ketones, aldehydes and alcohols. ${ }^{14-17}$ When using catalysts, the degree of deoxygenation is generally enhanced..$^{18}$ In such cases, the $\mathrm{C}$ number in the products is not always lower than the $\mathrm{C}$ number of the original feed. ${ }^{19-21}$ When the catalysts have strong acid sites, the amount of liquid alkenes and alkanes is decreased whereas important amounts of aromatic compounds are formed. ${ }^{22}$

Numerous studies have considered the use of model compounds to help understand some mechanistic aspects of the decomposition of triglyceride molecules due to their high complexity. Together with the cracking of saturated fatty acids, like stearic and palmitic acids formed during the hydrocracking of triglycerides, the use of oleic acid as a model molecule has been used to simulate what can occur in the absence of added hydrogen. ${ }^{21-29} \mathrm{~A}$ recent study on the pyrolysis of oleic acid in an autogeneous atmosphere, between 350 and $450{ }^{\circ} \mathrm{C}$, confirmed that both decarboxylation and decarbonylation took place in the reactor, but also revealed internal cracking at the allylic $\mathrm{C}$ position, leading to a predominance of C6-C10 hydrocarbons in the liquid products and the formation of $\mathrm{C} 9$ and $\mathrm{C} 10$ fatty acids. ${ }^{30}$ The amount of fatty acids decreased when the temperature of pyrolysis was increased, whereas the amount of mono- and poly-aromatic compounds increased. A recent study from our group described the flash pyrolysis of micro amounts of fatty compounds adsorbed on different solid catalysts, NaZSM-5, HZSM-5, $\gamma$-alumina, SAPO-5 and NiMo/SAPO-5, as a rapid way to screen some catalyst properties and confirm the presence of even minute amounts of products, especially primary reaction intermediates. ${ }^{31}$

The present work studies the flash pyrolysis of oleic acid, as it is the main fatty acid in most triglycerides taken from vegetable oils. Supported nickel catalysts were used to increase the deoxygenation process. We pre-adsorbed a very small amount of oleic acid on the surface of the catalysts in order to limit the influence of pyrolysis without catalyst. Thus, we could study the role of the catalyst in the initial steps of the decomposition of oleic acid.

\section{Experimental}

\section{Preparation of the catalysts}

Supported nickel catalysts with 10 wt.\% Ni (as NiO) were prepared by impregnation with an excess of aqueous solution of nickel(II) nitrate hexahydrate (Merck PA). The supports used were a transition alumina (Pural Sasol), and a commercial silica (Kali Chemie AF125), both in powder form. The solids obtained after evaporation in a rotating device were dried at $110^{\circ} \mathrm{C}$ in static air, manually ground for homogenization and calcined under air at $650{ }^{\circ} \mathrm{C}$ (heating rate of $10{ }^{\circ} \mathrm{C} \mathrm{min}^{-1}$ ) to generate the calcined catalysts precursors. Supports impregnated with pure water were treated in the same way as the supported catalysts in order to have a true reference carrier when necessary.

\section{Addition of oleic acid onto the catalysts}

$\mathrm{NiO} /$ silica and $\mathrm{NiO} /$ alumina after a new drying at $150{ }^{\circ} \mathrm{C}$ were mixed with small amounts of pure oleic acid (OA) (Sigma Aldrich $>93 \%$ ), in a mass proportion of $1 \mathrm{~g}$ of catalyst for $0.1 \mathrm{~g}$ of OA, under permanent manual agitation to allow complete spreading of the OA. At the end of this "pseudo" impregnation, the catalysts maintained their powder form. They are referred to as $\mathrm{OA} / \mathrm{NiO} /$ support in 
the following sections. The use of a high catalyst:reactant ratio was to provide high availability of catalytic sites and minimize the influence of thermal pyrolysis.

\section{Characterization of the catalysts}

Pure nickel nitrate and nickel nitrate deposited on both supports at the end of the drying treatment, as well as $\mathrm{OA} / \mathrm{NiO} /$ silica and $\mathrm{OA} / \mathrm{NiO} /$ alumina, were characterized by thermogravimetric/differential thermal analysis (TG/DTA) using a Perkin Elmer STA 6000 instrument. The experiments were conducted under a synthetic airflow rate of $20 \mathrm{~mL} \mathrm{~min}^{-1}$ between 30 and $600{ }^{\circ} \mathrm{C}$ at a heating rate of $10{ }^{\circ} \mathrm{C} \mathrm{min}^{-1}$. The reduction of supported $\mathrm{NiO}$ was done using a homemade temperature programmed reduction (TPR) equipment, at a heating rate of $10{ }^{\circ} \mathrm{C} \mathrm{min}^{-1}$ up to $800{ }^{\circ} \mathrm{C}$, using a mixture of $\mathrm{H}_{2} / \operatorname{argon}(1.5 \mathrm{vol} . \%$ of hydrogen)

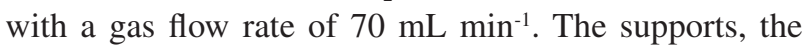
calcined $\mathrm{NiO}$ supported samples and the reduced catalysts at the end of TPR were characterized by X-ray diffraction (XRD) (Shimadzu diffractometer, model 6000) using the $\mathrm{CuK} \alpha$ radiation, between 10 and $80^{\circ}$ at a scanning rate of $2^{\circ} \mathrm{min}^{-1}$. The accelerating voltage and the current employed were $40 \mathrm{kV}$ and $30 \mathrm{~mA}$, respectively. The acidity of the catalysts was determined by using pyridine as probe molecule in the same TG Perkin Elmer equipment. An amount of $3 \mathrm{mg}$ of catalyst was pre-treated from 35 to $110{ }^{\circ} \mathrm{C}$ for $30 \mathrm{~min}$ to remove humidity and then heated to $550{ }^{\circ} \mathrm{C}$ at $20{ }^{\circ} \mathrm{C} \mathrm{min}^{-1}$ to remove chemisorbed water. After cooling the sample an amount of $1 \mu \mathrm{L}$ of pyridine per mg of catalyst was carefully added to the catalyst at $120^{\circ} \mathrm{C}$. The desorption of pyridine excess was carried out at the same temperature until reaching equilibrium, after about $60 \mathrm{~min}$. The chemisorbed pyridine was desorbed by heating up to $550{ }^{\circ} \mathrm{C}$ at $10{ }^{\circ} \mathrm{C} \mathrm{min}{ }^{-1}$ and the loss of mass was recorded with temperature. Specific surface area of the catalysts was determined by the Brunauer-EmmettTeller (BET) method in a Quantachrome NOVA-2000 equipment at $77 \mathrm{~K}\left(-196{ }^{\circ} \mathrm{C}\right)$ with nitrogen adsorption. Samples were pre-treated at $250{ }^{\circ} \mathrm{C}$ for $2 \mathrm{~h}$ under vacuum before measurement.

\section{Flash pyrolysis experiments}

The flash pyrolysis of pure OA and OA adsorbed on both $\mathrm{NiO} /$ supported samples were performed in a Pyroprobe CDS-5200 micropyrolysis set up, linked to a gas chromatography/mass spectrometry (GC/MS) analysis system (Shimadzu GC-MS QP 2010 Plus). The powdered sample of the OA/catalyst was placed in a $2 \mathrm{~mm} \times 25 \mathrm{~mm}$ quartz tube between quartz wool plugs, in an amount of around $1.0 \mathrm{mg}$ of catalyst with $0.1 \mathrm{mg}$ of impregnated oleic acid. The quartz tube was placed inside a resistive platinum coil heater. The flash pyrolysis was conducted at $650{ }^{\circ} \mathrm{C}$ for $0.25 \mathrm{~min}$, at a heating rate estimated as $1000^{\circ} \mathrm{C} \mathrm{min}^{-1}$ with

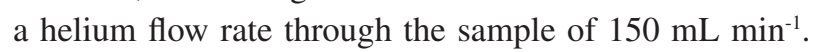
After pyrolysis, the vapors and gases flowed to the GC injector through a transfer line heated at $170{ }^{\circ} \mathrm{C}$, as shown in Figure 1. The chromatographic analysis was performed in a DB-5MS analytical column $(30 \mathrm{~m} \times 0.25 \mathrm{~mm} \times 0.25 \mu \mathrm{m})$, with a helium flow rate through the column of $1 \mathrm{~mL} \mathrm{~min}^{-1}$. The column program was $5 \mathrm{~min}$ at $45^{\circ} \mathrm{C}$, heating to $280^{\circ} \mathrm{C}$ at a heating rate of $4{ }^{\circ} \mathrm{C} \mathrm{min}^{-1}$, with a 10 min stay at $280^{\circ} \mathrm{C}$. The ion source was maintained at $280^{\circ} \mathrm{C}$ and the interface at $290{ }^{\circ} \mathrm{C}$. The $\mathrm{m} / \mathrm{z}$ data were measured between 40 and 400. The chromatographic peaks of the pyrolysis products were identified using the National Institute of Standards and Technology (NIST) library standards as well as comparing with data from the literature. The probability of products identification was better than $90 \%$ for the great majority of the peaks. The standard deviations of the main peaks in some replicated experiments were smaller than $25 \%$.

\section{Results and Discussion}

\section{Characterization of the catalysts}

Figure 2 presents TG and derivative thermogravimetry (DTG) curves obtained during the decomposition of nickel nitrate hexahydrate either pure or impregnated on both alumina and silica. The decomposition of pure nickel nitrate shows four main mass losses, with maxima at around 100, 180,240 and $320^{\circ} \mathrm{C}$. The three low temperature mass losses

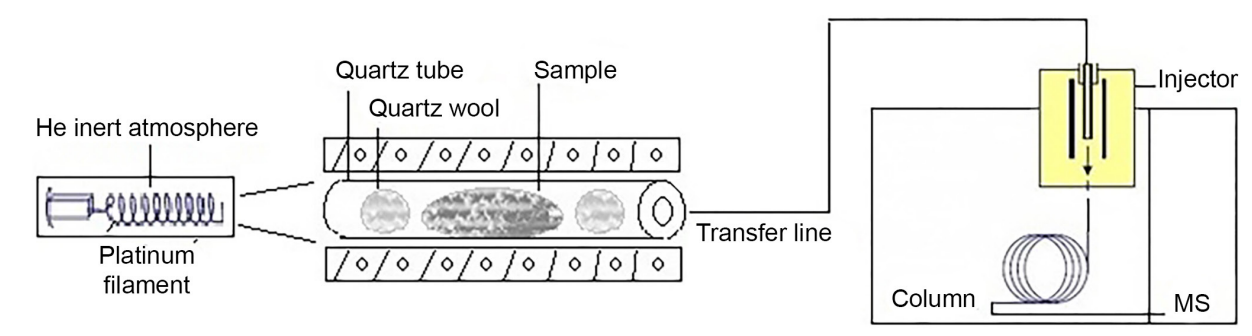

Figure 1. Pyroprobe reactor system (not to scale): sample in a $2 \mathrm{~mm} \times 25 \mathrm{~mm}$ quartz tube, platinum coil heater; transfer line to the GC injector; GC chromatograph; MS detector. 
are attributed to water loss, whereas the high temperature event is due to $\mathrm{NO}_{x}$ release..$^{32,33} \mathrm{Above} 650^{\circ} \mathrm{C}$, no further mass loss was observed suggesting a complete decomposition of pure nickel nitrate to nickel oxide. In the presence of both supports, a first mass loss ending between 150 and $170{ }^{\circ} \mathrm{C}$ is attributed to water release from the support. Further mass losses vary with the nature of the support, a clear mass loss process appearing only with nickel nitrate deposited onto silica, with a maximum rate at around $270^{\circ} \mathrm{C}$. The other steps are not well resolved. Table 1 shows the mass loss percentage from the decomposition of pure or supported nickel nitrate on silica and alumina, obtained from the TG curves. Figure 2 and Table 1 show that the decomposition temperature of the nickel nitrate for the release of NOx follows the order: $\mathrm{NiO} /$ alumina $>\mathrm{NiO} /$ silica. This suggests that the interaction of the nickel with alumina is higher than with silica.

The DTA curves presented in Figure 3 show some similarities to the DTG curves, all thermal processes being endothermic. For pure nickel nitrate, there are five
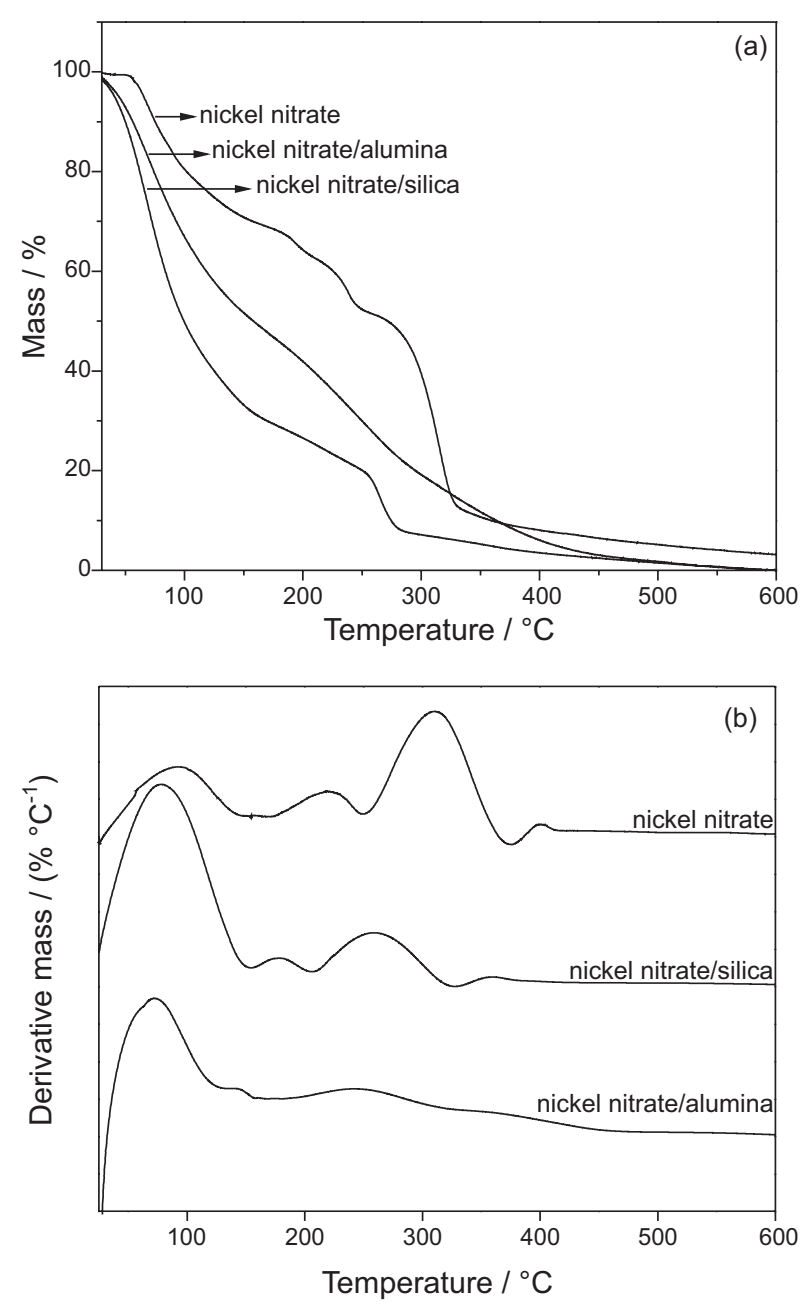

Figure 2. TG (a) and DTG (b) curves under air atmosphere for nickel nitrate, either pure or impregnated on both silica and alumina, up to $600{ }^{\circ} \mathrm{C}\left(10^{\circ} \mathrm{C} \mathrm{min}^{-1}\right)$.

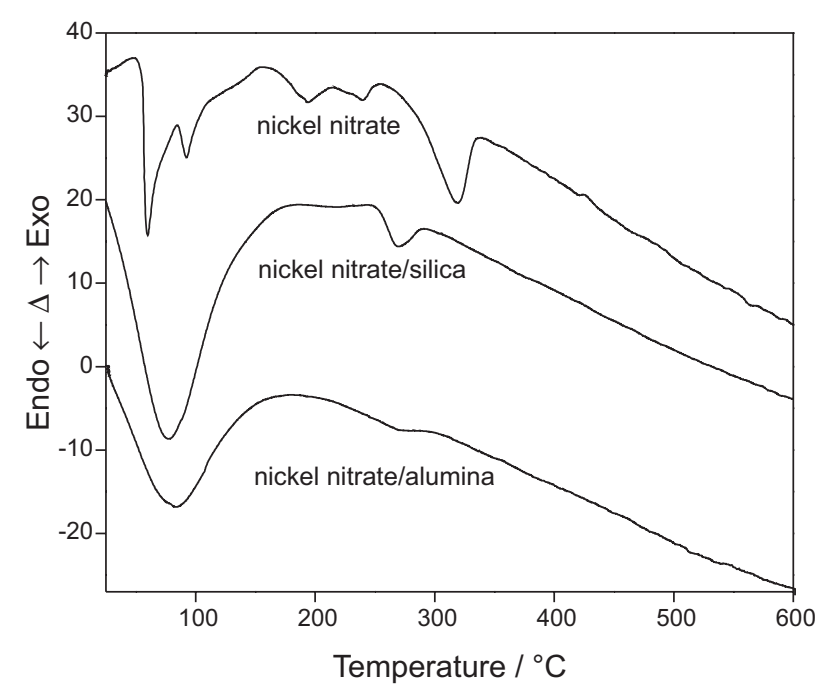

Figure 3. DTA curves under air atmosphere for nickel nitrate, either pure or impregnated on both silica and alumina, up to $600^{\circ} \mathrm{C}\left(10^{\circ} \mathrm{C} \mathrm{min}^{-1}\right)$.

main peaks, the first one with a maximum at $50{ }^{\circ} \mathrm{C}$, due to both a fusion process of the hydrated salt and the loss of a first molecule of water. The second, third and fourth events at around 100,200 and $250{ }^{\circ} \mathrm{C}$ are essentially due to water release, whereas the fifth one, with a maximum at around $320^{\circ} \mathrm{C}$ is due to $\mathrm{NO}_{x}$ elimination. For the supported materials, the low temperature endotherm is due to water elimination from the supports, the process ending at $180^{\circ} \mathrm{C}$. The endothermic peaks observed at around $270^{\circ} \mathrm{C}$ for both nickel/silica and nickel/alumina precursors are attributed to $\mathrm{NO}_{\mathrm{x}}$ elimination. In this latter case a stronger interaction of the nickel precursor with alumina decreases the decomposition rate of the precursor. TG curves in Figure 2a show that the decomposition of nickel nitrate on silica is faster than on alumina. In both Figures 2 and 4, no further mass loss and/or clear thermal event occurs above $500{ }^{\circ} \mathrm{C}$, suggesting that the precursor salt of nickel is fully decomposed at this temperature. The difference in decomposition behavior between both supported materials suggest that the interaction of the impregnated nickel salt is different on both supports, a situation that may lead to different interactions with the support of the $\mathrm{NiO}$ particles formed at the end of heat treatment, in agreement with data from the literature. ${ }^{34}$

Table 2 gives some properties of the supported catalysts either in oxidized or reduced form such as temperature reduction interval, crystallite mean size, specific surface area and acidity. This table shows that the reduction of $\mathrm{NiO} /$ silica is completed at $460{ }^{\circ} \mathrm{C}$, whereas the reduction of $\mathrm{NiO} /$ alumina is completed at $750{ }^{\circ} \mathrm{C}$. The rather low reducibility of the present supported $\mathrm{NiO}$ is essentially due to the experimental conditions used, where the partial pressure of hydrogen is low. As the reduction rate of 
Table 1. Mass loss percentage from the decomposition of pure or supported nickel nitrate on silica and alumina, from the TG curves

\begin{tabular}{lcccccc}
\hline Material & $\begin{array}{c}1^{\text {st }} \text { Temperature water } \\
\text { release } /{ }^{\circ} \mathrm{C}\end{array}$ & $1^{\text {st }}$ Mass loss $/ \%$ & $\begin{array}{c}2^{\text {nd }} \text { Temperature } \\
\text { water release } /{ }^{\circ} \mathrm{C}\end{array}$ & $2^{\text {nd }}$ Mass loss $/ \%$ & $\begin{array}{c}3^{\text {rd }} \text { Temperature NOx } \\
\text { release } /{ }^{\circ} \mathrm{C}\end{array}$ & $3^{\text {rd }}$ Mass loss $/ \%$ \\
\hline $\mathrm{Ni}\left(\mathrm{NO}_{3}\right)_{2} \cdot \mathrm{H}_{2} \mathrm{O}$ & $30-150$ & 29 & $150-260$ & 19 & $260-390$ & 43 \\
$\mathrm{Ni}$ nitrate/silica & $30-150$ & 65 & $150-220$ & 9 & $220-320$ & 18 \\
Ni nitrate/alumina & $30-120$ & 39 & $120-170$ & 4 & $170-310$ & 30 \\
\hline
\end{tabular}

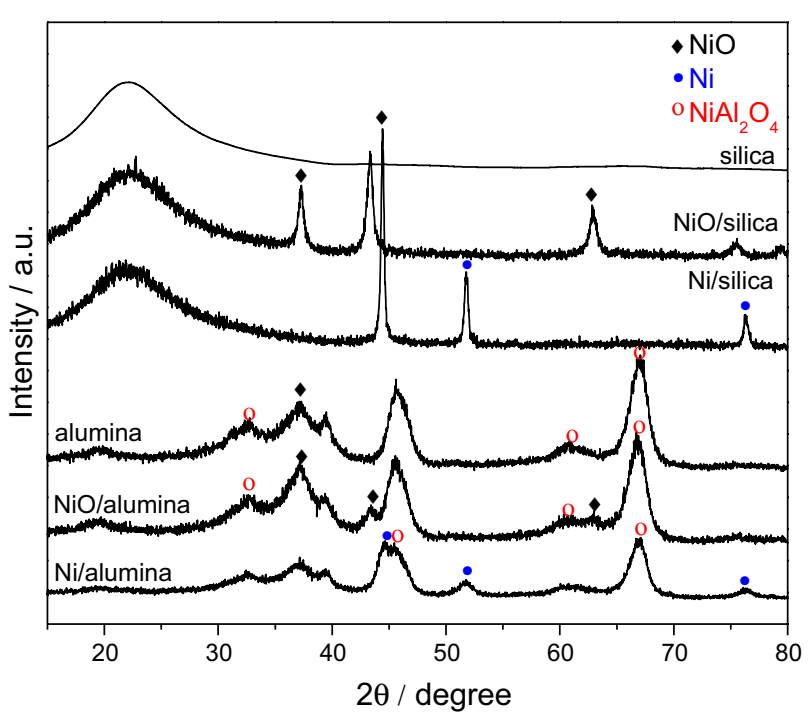

Figure 4. X-ray diffractograms of silica, $\mathrm{NiO} /$ silica, alumina, $\mathrm{NiO} /$ alumina after calcination at $650{ }^{\circ} \mathrm{C}$ and reduced $\mathrm{Ni} /$ silica and $\mathrm{Ni} /$ alumina after TPR at $800^{\circ} \mathrm{C}$.

unsupported nickel oxide presents a positive reaction order regarding the hydrogen pressure, the low pressure used in the present TPR experiments does not favor the metal reduction, but it may allow possible NiO-support interactions during the heating ramp, increasing the temperature of the reduction process. Such situation may affect the final state of the reduced nickel. ${ }^{35}$ The reduction temperature of nickel oxide on alumina is higher than on silica suggesting that the interaction of $\mathrm{NiO}$ with alumina is higher than with silica. A limited formation of nickel aluminate, at the interface between alumina and supported $\mathrm{NiO}$ particles, can also be advocated to explain the lower reducibility of alumina supported nickel oxide. This situation will be further discussed during the analysis of XRD data (Figure 4). Table 2 also shows that the specific surface area of $\mathrm{NiO} /$ silica is twice as much the area of $\mathrm{NiO} /$ alumina. The acidity of $\mathrm{NiO} /$ alumina $(0.15 \mathrm{mmol}$ of pyridine $\mathrm{g}^{-1}$ ) is almost three time higher than the acidity of $\mathrm{NiO} /$ silica.

Figure 4 presents the XRD diffractograms for silica, $\mathrm{NiO} /$ silica, reduced $\mathrm{Ni} /$ silica after TPR, alumina, $\mathrm{NiO}$ /alumina and reduced Ni/alumina. The XRD results of the silica supported catalyst present a wide peak at $2 \theta=22^{\circ}$, due to the quasi amorphous structure of the silica and diffraction lines at $2 \theta=37,43,63^{\circ}$ typical of $\mathrm{NiO}^{36}$ Diffraction lines attributed to metallic nickel $\mathrm{Ni}^{0}(2 \theta=45$, 52 and $76^{\circ}$ ) are observed after TPR, the amorphous line of silica support being unaltered. Therefore, on silica, supported $\mathrm{NiO}$ is obtained at the end of the calcination at $650{ }^{\circ} \mathrm{C}$ of the supported nickel nitrate, and metallic nickel at the end of TPR.

In Figure 4, the XRD diagram of alumina is very typical of transition alumina. The lines at $2 \theta=19,32$, $37,39,45,60$ and $67^{\circ}$ are close to those described in the case of $\gamma$-alumina. ${ }^{37}$ In this case, peaks due to alumina and $\mathrm{NiO}$ are partially merged. Only the diffraction lines of $\mathrm{NiO}$ at 43 and $63^{\circ}$ are clearly observed. This observation confirms that with alumina, $\mathrm{NiO}$ is also obtained at the end of the calcination at $650{ }^{\circ} \mathrm{C}$. However, Figure 3 shows that the presence of nickel aluminate $\mathrm{NiAl}_{2} \mathrm{O}_{4}$ cannot be ruled out since its XRD lines overlap with the lines characteristic of transition alumina. ${ }^{38}$ After TPR, $\mathrm{Ni}^{0}$ diffraction lines are clearly present at $2 \theta=52$ and $76^{\circ}$. Therefore, although the reduction process of the catalyst supported on alumina requires higher temperature under TPR conditions than the reduction of the catalyst supported on silica, the reduction mainly transforms $\mathrm{NiO}$ to metallic nickel in both cases. We were able to estimate a crystallite size of

Table 2. Reduction temperature of $\mathrm{NiO}$ to metalic nickel from TPR, NiO or Ni crystallite particle size and specific surface area and acidity of NiO/silica and $\mathrm{NiO}$ /alumina

\begin{tabular}{lcccc}
\hline Catalyst & Reduction temperature $/{ }^{\circ} \mathrm{C}$ & $\mathrm{NiO}$ or Ni crystallite size $/ \mathrm{nm}$ & Specific surface area $/\left(\mathrm{m}^{2} \mathrm{~g}^{-1}\right)$ & Acidity $/\left(\mathrm{mmol}\right.$ pyridine $\left.\mathrm{g}^{-1}\right)$ \\
\hline $\mathrm{NiO} /$ silica & - & 22.1 & 308 & 0.06 \\
$\mathrm{NiO} /$ alumina & - & 12.5 & 152 & 0.15 \\
$\mathrm{Ni} /$ silica & $340-460$ & 15.0 & - & - \\
$\mathrm{Ni} /$ alumina & $440-750$ & 9.0 & - & - \\
\hline
\end{tabular}


$15 \mathrm{~nm}$ for $\mathrm{Ni} \%$ silica and smaller than $9 \mathrm{~nm}$ in the case of $\mathrm{Ni}^{\circ} /$ alumina using the Scherrer equation with the diffraction line at 52 and $76^{\circ}$ (Table 2). ${ }^{39}$ Therefore, after reduction, the $\mathrm{Ni}$ crystallite size is different on silica and alumina, probably as a consequence of the differences of $\mathrm{NiO}$ interaction with both supports. These differences of interaction probably started during impregnation/drying and/or decomposition processes of the nickel precursor as suggested by the different decomposition profiles observed in both DTG (Figure2) and DTA (Figure 3). Table 2 also shows that the particle size of $\mathrm{NiO}$ on silica is bigger than the size of $\mathrm{NiO}$ on alumina.

\section{DTG of oleic acid, either pure or adsorbed on $\mathrm{NiO} /$ support catalysts}

Figure 5 presents the TG and DTG curves obtained under nitrogen atmosphere for $\mathrm{OA} / \mathrm{NiO} /$ silica, $\mathrm{OA} / \mathrm{NiO} /$ alumina and pure $\mathrm{OA}$ as reference. For pure $\mathrm{OA}$, a single mass loss
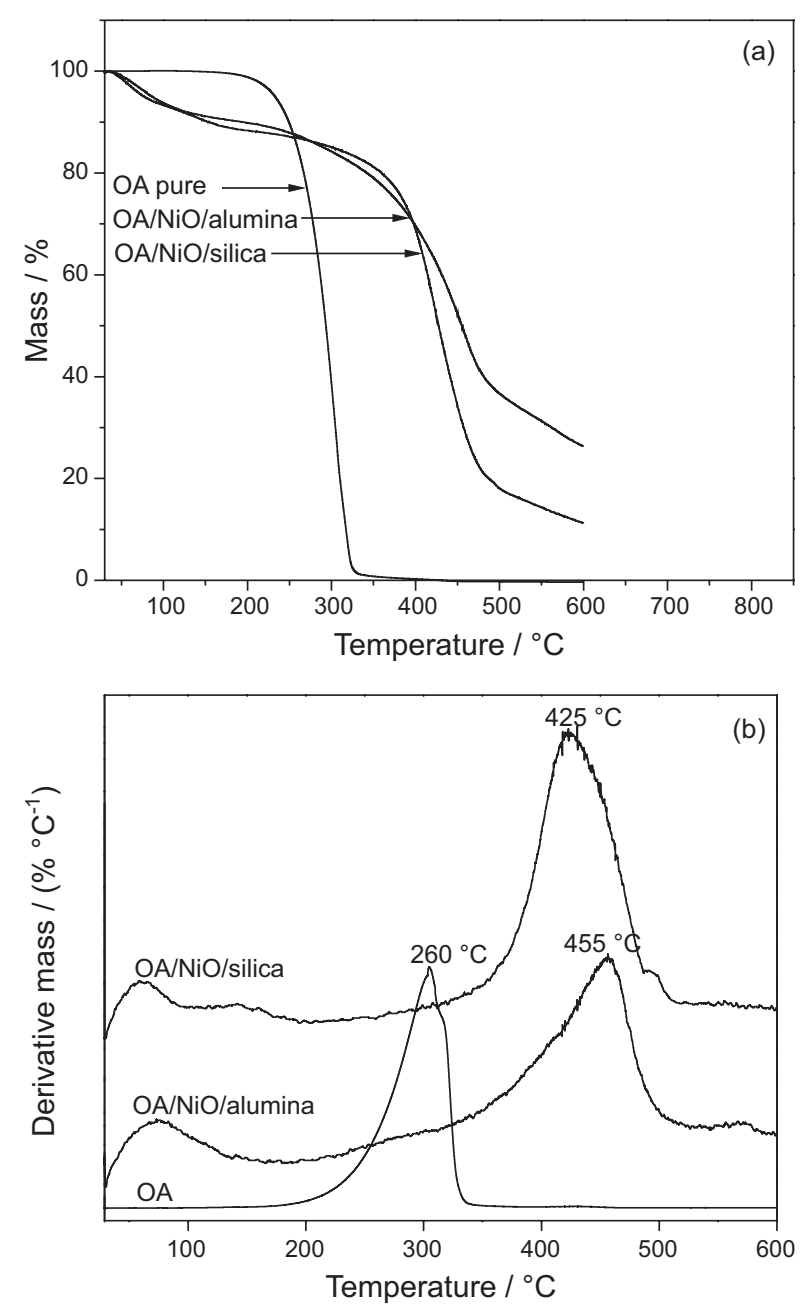

Figure 5. TG (a) and DTG (b) curves under nitrogen atmosphere for pure $\mathrm{OA}$ and $\mathrm{OA}$ adsorbed on both $\mathrm{NiO} /$ silica and $\mathrm{NiO} /$ alumina, up to $600{ }^{\circ} \mathrm{C}\left(10^{\circ} \mathrm{C} \mathrm{min}^{-1}\right)$. is observed with the maximum rate at around $260{ }^{\circ} \mathrm{C}$. In the case of OA adsorbed on both catalysts, after a mass loss before $150-200{ }^{\circ} \mathrm{C}$ attributed essentially to water desorption from the catalyst surface, the main mass loss occurs at higher temperatures by comparison with pure OA mass loss. Thus, the adsorption of OA onto the catalysts increases the temperature of the mass loss due to OA release and/or decomposition. Furthermore, the differences in mass loss profiles for pure OA and $\mathrm{OA}$ adsorbed on both $\mathrm{NiO}$ /alumina and $\mathrm{NiO}$ /silica catalysts, as well as the differences in the temperature of maximum mass loss rate, indicate that the strength of OA adsorption varies with the nature of the catalyst. Consequently, it can be supposed also that the pyrolysis of OA, either unsupported or supported on both catalysts will generate different families of products, both catalysts retaining more strongly some pyrolysis products when compared with pyrolysis without catalyst. One further point must be added: above $600{ }^{\circ} \mathrm{C}$, no clear mass loss event is observed, justifying in part, together with literature data, ${ }^{17}$ the choice of $650{ }^{\circ} \mathrm{C}$ as the final flash pyrolysis temperature used in the next section.

Flash pyrolysis of oleic acid, either pure or adsorbed on $\mathrm{NiO} /$ support catalysts

Figure 6 shows the peaks of products (pyrogram) obtained during the flash pyrolysis at $650{ }^{\circ} \mathrm{C}$ of pure $\mathrm{OA}$ and $\mathrm{OA}$ adsorbed on both $\mathrm{NiO} /$ silica and $\mathrm{NiO} /$ alumina. Table 3 summarizes the main classes of products identified. During the pyrolysis of pure OA, the percentage of the products formed up to the retention time of $41.1 \mathrm{~min}$ represents less than $10 \%$ of the whole area of the pyrogram. The main peaks on the right side of the pyrogram, with retention times equal and higher than $41.1 \mathrm{~min}$ are due to $\mathrm{C} 14$ and $\mathrm{C} 16$ fatty acids and to untransformed $\mathrm{C} 18$ oleic acid (retention time of $52 \mathrm{~min}$ ). That part of the pyrogram represents more than $90 \%$ of the area of the whole pyrogram. Therefore, during the flash pyrolysis of pure OA at $650{ }^{\circ} \mathrm{C}$, fatty acids with shorter $\mathrm{C}$ chain are obtained before DCO can occur. At retention times lower than $41.1 \mathrm{~min}$, many other oxygenated products are found: among them, dodecanoic $(0.25 \%)$, undecylenic $(0.16 \%)$, decanoic $(0.41 \%)$, octanoic $(0.31 \%)$, 7 -octenoic $(0.07 \%)$, heptanoic $(0.10 \%)$ and acetic $(0.09 \%)$ acids are identified. Aldehydes, alcohols and ethers are also identified. Finally, the amount of deoxygenated compounds, mainly monounsaturated alkenes, does not represent more than $3.8 \%$ of the whole pyrogram. Hence, the flash pyrolysis of pure $\mathrm{OA}$ in the present experimental conditions is limited and does not favor deoxygenation. 

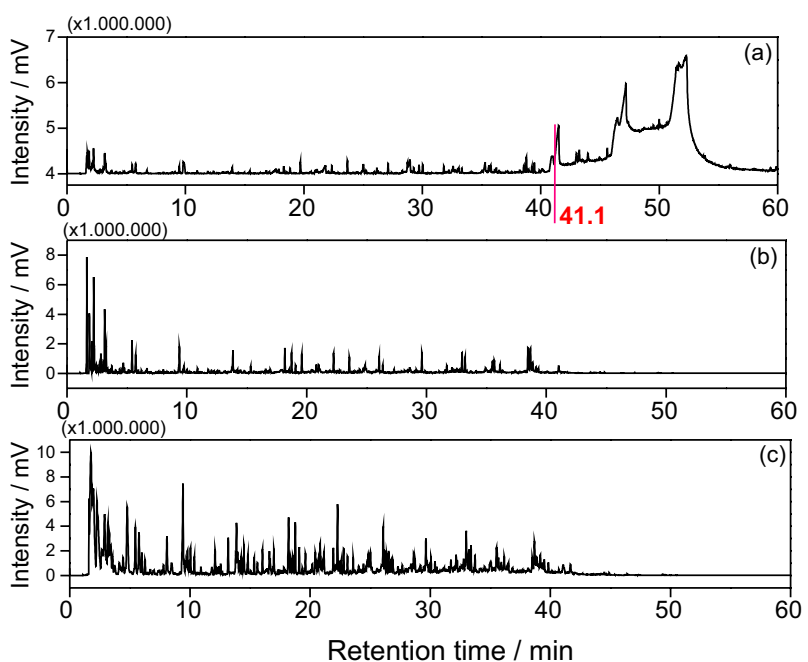

Figure 6. Total ion chromatograms showing the products from flash pyrolysis for pure oleic acid (OA) (a) and of OA adsorbed on both $\mathrm{NiO} /$ silica (b) and $\mathrm{NiO} /$ alumina (c).

Table 3. General distribution of compounds analyzed at the end of flash pyrolysis of pure OA, and $\mathrm{OA}$ adsorbed on both $\mathrm{NiO} /$ silica and $\mathrm{NiO} /$ alumina

\begin{tabular}{lccc}
\hline System & NI area / \% & OC area / \% & HC area / \% \\
\hline OA & 25.30 & 71.78 & 3.82 \\
OA/NiO/silica & 11.46 & 8.47 & 80.07 \\
OA/NiO/alumina & 13.50 & 5.92 & 78.57 \\
\hline
\end{tabular}

NI: Non-identified compounds; OC: oxygenated compounds; HC: deoxygenated compounds (hydrocarbons).

The two pyrograms obtained when OA is adsorbed on both $\mathrm{NiO}$ /silica and $\mathrm{NiO}$ /alumina hardly show the presence of residual unconverted OA: the contact between the catalyst surface and the adsorbed OA allows a complete transformation of oleic acid. Contrary to pyrolysis without catalyst, the pyrolysis in the presence of catalysts reveals the formation of a very important amount of light products. Among these products it is possible to observe peaks due to homologous compounds like 1-alkenes (peaks 1, 3, 4, 5, 6), as shown in Figure 7, where the names of organic compounds are attributed to some peaks between the retention times of 5 and $25 \mathrm{~min}$.

Table 4 gives the semi-quantitative distribution of the deoxygenated compounds (area percentage of saturated, monounsaturated, polyunsaturated and aromatic compounds). Whereas Table 3 indicated that the amount of deoxygenated compounds (hydrocarbons) is practically similar for both $\mathrm{OA} / \mathrm{NiO} /$ alumina and $\mathrm{OA} / \mathrm{NiO} /$ silica, Table 4 shows important differences between the distribution of the hydrocarbon families obtained after pyrolysis at $650^{\circ} \mathrm{C}$ of $\mathrm{OA}$ adsorbed onto both catalysts: in the case of $\mathrm{NiO} /$ alumina, the pyrolysis of $\mathrm{OA}$ leads to an important amount of aromatic products, a family
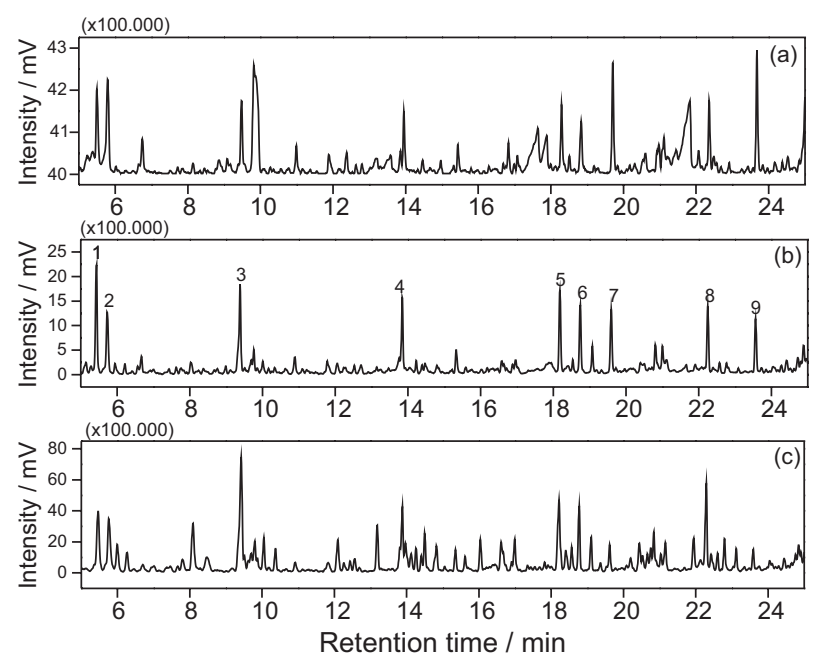

Figure 7. Total ion chromatograms between retention times 5-25 min of the products from flash pyrolysis for pure oleic acid (OA) (a) and of $\mathrm{OA}$ adsorbed on both $\mathrm{NiO} /$ silica (b) and $\mathrm{NiO} /$ alumina (c). The main compounds in pyrogram (b) are: (1) octene, (2) $n$-octane, (3) 1-nonene, (4) 1-decene, (5) 1-undecene, (6) (E)-2-undecene, (7) 1,4-undecadiene, (8) 1-dodecene, (9) 6-dodecyne.

Table 4. Area percentage of the deoxygenated products formed during the flash pyrolysis of $\mathrm{AO}$ either pure or adsorbed on both $\mathrm{NiO} /$ silica and $\mathrm{NiO} /$ alumina

\begin{tabular}{lcccc}
\hline System & SAT area / $\%$ & $\begin{array}{c}\text { MO area / } \\
\%\end{array}$ & $\begin{array}{c}\text { PO area / } \\
\%\end{array}$ & $\begin{array}{c}\text { A area / } \\
\%\end{array}$ \\
\hline OA & 0.33 & 2.59 & 0.92 & 0 \\
OA/NiO/silica & 10.82 & 51.19 & 14.72 & 3.34 \\
OA/NiO/alumina & 6.60 & 42.30 & 8.12 & 21.55 \\
\hline
\end{tabular}

SAT: Saturated; MO: monoolefins; PO: polyunsaturated hydrocarbons; A: aromatics.

of compounds produced in a much lower amount with $\mathrm{OA} / \mathrm{NiO} /$ silica. On the other hand, $\mathrm{OA} / \mathrm{NiO} /$ silica produces more alkanes, alkenes and polyunsaturated hydrocarbons, such as dienes, trienes and alkynes than $\mathrm{OA} / \mathrm{NiO} /$ alumina.

Table 5 identifies the main aromatic products formed during pyrolysis with both catalysts. In the case of pyrolysis of OA without catalyst, no aromatic compound was detected analyzing peaks with a percentage area equal to or higher than $0.06 \%$. For $\mathrm{OA} / \mathrm{NiO} /$ silica, together with benzene, linear alkylbenzenes with lateral chain containing 1, 2, 3, 4 and $6 \mathrm{C}$ were found, as well as one dialkyl benzene. For $\mathrm{OA} / \mathrm{NiO} /$ alumina, more than 50 aromatic compounds were detected, among them linear alkylbenzenes, with lateral carbon chain between 1 and $11 \mathrm{C}$, representing more than $50 \%$ of all the aromatic compounds detected. A few number of alkenyl benzenes, an important number of di- and trialkyl benzenes and a rather large number of polyaromatic compounds, such as indane/indene, naphthalenes and fluorene, either unalkylated or with limited alkyl chains, were also identified. 
Table 6 summarizes the amounts of monoalkyl benzenes formed with both $\mathrm{OA} / \mathrm{NiO} /$ silica and $\mathrm{OA} / \mathrm{NiO} /$ alumina. Monoalkyl benzenes have been observed in preceding studies dealing with cracking/hydrocracking of fatty compounds, but up to the time of our study, a general sequence of alkyl benzenes as observed with $\mathrm{OA} / \mathrm{NiO} /$ alumina

Table 5. Main aromatic compounds formed during the pyrolysis of oleic acid adsorbed on both NiO/alumina and NiO/silica. The second column is the retention time $t_{\mathrm{R}}(\mathrm{min})$, the third is the name of the aromatic compound, the fourth is the chemical formula, the fifth and sixth are the area percentage from the pyrogram, respectively on $\mathrm{NiO} /$ alumina and $\mathrm{NiO} /$ silica

\begin{tabular}{|c|c|c|c|c|c|}
\hline entry & $t_{R} / \min$ & Compound & Formula & NiO/alumina & $\mathrm{NiO} /$ silica \\
\hline 1 & 2.897 & Benzene & $\mathrm{C}_{6} \mathrm{H}_{6}$ & 2.89 & 1.28 \\
\hline 2 & 4.783 & Toluene & $\mathrm{C}_{7} \mathrm{H}_{8}$ & 3.41 & 0.78 \\
\hline 3 & 8.088 & Ethylbenzene & $\mathrm{C}_{8} \mathrm{H}_{10}$ & 1.24 & 0.34 \\
\hline 4 & 8.470 & $m$-p-Xylene & $\mathrm{C}_{8} \mathrm{H}_{10}$ & 0.57 & - \\
\hline 5 & 12.097 & Propyl-benzene & $\mathrm{C}_{9} \mathrm{H}_{12}$ & 0.64 & 0.31 \\
\hline 6 & 12.436 & 1-Ethyl-3-methyl-benzene & $\mathrm{C}_{9} \mathrm{H}_{12}$ & 0.19 & - \\
\hline 7 & 13.188 & 1-Ethyl-2-methyl-benzene & $\mathrm{C}_{9} \mathrm{H}_{12}$ & 0.81 & - \\
\hline 8 & 13.140 & (1-Methylethyl)-benzene & $\mathrm{C}_{9} \mathrm{H}_{12}$ & - & 0.15 \\
\hline 9 & 13.968 & 1-Propenyl-benzene & $\mathrm{C}_{9} \mathrm{H}_{10}$ & 0.63 & - \\
\hline 10 & 15.053 & 1,2,4-Trimethyl-benzene & $\mathrm{C}_{9} \mathrm{H}_{12}$ & 0.09 & - \\
\hline 11 & 15.618 & Indane & $\mathrm{C}_{9} \mathrm{H}_{10}$ & 0.25 & - \\
\hline 12 & 16.041 & Indene & $\mathrm{C}_{9} \mathrm{H}_{8}$ & 0.53 & - \\
\hline 13 & 16.386 & 1-Methyl-3-propyl-benzene & $\mathrm{C}_{10} \mathrm{H}_{14}$ & 0.13 & - \\
\hline 14 & 16.618 & Butyl-benzene & $\mathrm{C}_{10} \mathrm{H}_{14}$ & 0.55 & 0.28 \\
\hline 15 & 16.990 & 1-Methyl-4-propyl-benzene & $\mathrm{C}_{10} \mathrm{H}_{14}$ & 0.58 & - \\
\hline 16 & 17.347 & (E)-1-Butenyl-benzene & $\mathrm{C}_{10} \mathrm{H}_{12}$ & 0.10 & - \\
\hline 17 & 17.436 & 1-Ethyl-2,3-dimethyl-benzene & $\mathrm{C}_{10} \mathrm{H}_{14}$ & 0.08 & - \\
\hline 18 & 17.547 & 1-Methyl-2-(1-methylethyl)-benzene & $\mathrm{C}_{10} \mathrm{H}_{14}$ & 0.09 & - \\
\hline 19 & 17.680 & 1-Methyl-1,2-propadienyl-benzene & $\mathrm{C}_{10} \mathrm{H}_{10}$ & 0.10 & - \\
\hline 20 & 17.819 & 1-Phenyl-1-butene & $\mathrm{C}_{10} \mathrm{H}_{12}$ & 0.17 & - \\
\hline 21 & 19.363 & (2-Methyl-1-propenyl)-benzene & $\mathrm{C}_{10} \mathrm{H}_{12}$ & 0.17 & - \\
\hline 22 & 19.529 & (E)-1-Butenyl-benzene & $\mathrm{C}_{10} \mathrm{H}_{12}$ & 0.07 & - \\
\hline 23 & 19.779 & 2,4-Dimethylstyrene & $\mathrm{C}_{10} \mathrm{H}_{12}$ & 0.07 & - \\
\hline 24 & 20.083 & 2,3-Dihydro-4-methyl-1 $H$-indene & $\mathrm{C}_{10} \mathrm{H}_{12}$ & 0.11 & - \\
\hline 25 & 20.197 & 1,3-Diethyl-5-methyl-benzene & $\mathrm{C}_{11} \mathrm{H}_{16}$ & 0.31 & - \\
\hline 26 & 20.439 & 3-Methyl-1 $H$-indene & $\mathrm{C}_{10} \mathrm{H}_{10}$ & 0.55 & - \\
\hline 27 & 20.754 & 1-Methyl-1 $H$-indene & $\mathrm{C}_{10} \mathrm{H}_{10}$ & 0.40 & - \\
\hline 28 & 21.160 & 1-Methyl-4-(2-methylpropyl)-benzene & $\mathrm{C}_{11} \mathrm{H}_{16}$ & 0.56 & - \\
\hline 29 & 21.941 & Azulene & $\mathrm{C}_{10} \mathrm{H}_{8}$ & 0.64 & - \\
\hline 30 & 23.036 & (1-Methyl-1-butenyl)-benzene & $\mathrm{C}_{11} \mathrm{H}_{14}$ & 0.09 & - \\
\hline 31 & 23.346 & 1-Methyl-2-(1-ethylpropyl)-benzene & $\mathrm{C}_{12} \mathrm{H}_{18}$ & 0.10 & - \\
\hline 32 & 23.484 & trans-1-Phenyl-1-pentene & $\mathrm{C}_{11} \mathrm{H}_{14}$ & 0.07 & - \\
\hline 33 & 24.046 & 1-Ethyl-4-(2-methylpropyl)-benzene & $\mathrm{C}_{12} \mathrm{H}_{18}$ & 0.19 & - \\
\hline 34 & 24.846 & Hexyl-benzene & $\mathrm{C}_{12} \mathrm{H}_{18}$ & 0.48 & 0.20 \\
\hline 35 & 25.030 & (1,3-Dimethylbutyl)-benzene & $\mathrm{C}_{12} \mathrm{H}_{18}$ & 0.62 & - \\
\hline 36 & 25.142 & 2,3-Dimethyl- $1 H$-indene & $\mathrm{C}_{11} \mathrm{H}_{12}$ & 0.20 & - \\
\hline 37 & 26.756 & 1-Methyl-naphthalene & $\mathrm{C}_{11} \mathrm{H}_{10}$ & 0.35 & - \\
\hline 38 & 28.625 & Heptyl-benzene & $\mathrm{C}_{13} \mathrm{H}_{20}$ & 0.51 & - \\
\hline 39 & 28.738 & 1-Methyl-2- $n$-hexylbenzene & $\mathrm{C}_{13} \mathrm{H}_{20}$ & 0.36 & - \\
\hline 40 & 29.806 & 2-Methyl-1,1'-biphenyl & $\mathrm{C}_{13} \mathrm{H}_{12}$ & 0.19 & - \\
\hline 41 & 30.704 & 2,3-Dimethyl-naphthalene & $\mathrm{C}_{12} \mathrm{H}_{12}$ & 0.06 & - \\
\hline 42 & 32.159 & Octyl-benzene & $\mathrm{C}_{14} \mathrm{H}_{22}$ & 0.41 & - \\
\hline 43 & 32.253 & (1-Methylheptyl)-benzene & $\mathrm{C}_{14} \mathrm{H}_{22}$ & 0.25 & - \\
\hline 44 & 35.519 & Nonyl-benzene & $\mathrm{C}_{15} \mathrm{H}_{24}$ & 0.55 & - \\
\hline 45 & 35.561 & (1-Methyl-nonyl)-benzene & $\mathrm{C}_{16} \mathrm{H}_{26}$ & 0.43 & - \\
\hline 46 & 35.921 & Fluorene & $\mathrm{C}_{13} \mathrm{H}_{12}$ & 0.36 & - \\
\hline 47 & 41.672 & Undecyl-benzene & $\mathrm{C}_{17} \mathrm{H}_{28}$ & 0.34 & - \\
\hline
\end{tabular}


has not been reported. ${ }^{30,40}$ In the industrial production of linear alkyl benzenes for detergent applications, the alkylation of olefins is conducted in the presence of a strong acidic medium, either with HF, or more recently with zeolite-type heterogeneous catalysts. ${ }^{41,42}$ The mechanism of this type of catalytic alkylation implies the participation of carbocations and acidic sites. Such a mechanism is rather unexpected under present conditions, although the carboxylic moieties may form acidic $\mathrm{OH}$ groups on metallic or support surface sites after adsorption of the acidic function under the form of carboxylate species. ${ }^{43,44}$ However, alumina-supported nickel catalysts have shown very high activity and selectivity in the alkylation of benzene with propene to form cumene..$^{45}$ Therefore, alkylation with supported nickel catalysts is possible, although the conditions of the present study are different from the conditions used by Jian et al. ${ }^{45}$ Maybe under the present experimental conditions, the linear alkyl benzenes have essentially been formed through an internal aromatization after or during decarboxylation. Molecules, such as linear alkyl cyclopentenes or linear alkyl cyclohexenes able to lose hydrogen on nickel sites to transform the alkylated cycloolefins to alkylated benzenes, are probably used as intermediate molecules. In fact, small amounts of cyclopentenes with linear alkyl chain containing $3,4,5,7$ and $8 \mathrm{C}$, and cyclohexenes with linear alkyl chain with 4 and $6 \mathrm{C}$ have been identified. However, the exact mechanism of formation of the family of alkylbenzenes during the pyrolysis of $\mathrm{OA}$ adsorbed on $\mathrm{NiO} /$ alumina is still unkown.

Table 7 shows the amounts of linear 1-alkenes in the 3 experiments. Whereas this amount is very limited for the pyrolysis of OA without catalyst (1.8\%), both $\mathrm{NiO} /$ alumina $(20.7 \%)$ and principally $\mathrm{NiO} /$ silica $(33.5 \%)$ decomposed OA towards 1-olefins with satisfactory selectivity. Although both catalysts help to decompose the adsorbed OA fully, differences in product distribution is clearly observed. It seems evident that the higher acidity of $\mathrm{NiO} /$ alumina compared with $\mathrm{NiO} /$ silica (Table 2) must play an important role in the formation of the isomers of linear olefins and in the formation of aromatic compounds, these latter compounds being probably formed also due to the dehydrogenating properties of nickel sites. Hydrogen transfer pathways, advocated for example during the decomposition of saturated fatty acids on activated alumina may probably occur in the present experimental conditions, together with the participation of adsorbed hydrogen on the metallic nickel surface, as hydrocarbons are able to reduce nickel oxide to metallic nickel at temperatures in the $400-500{ }^{\circ} \mathrm{C}$ range..$^{19,46}$

Although the amount of oxygenated compounds is not very high, it is important to indicate that $\mathrm{CO}_{2}$ and acetates were observed with the $\mathrm{NiO} /$ alumina sample, but not with $\mathrm{NiO} /$ silica. Such a situation is probably linked to the partial adsorption of oleic acid through carboxylate species on the alumina surface, such species being practically absent when the adsorption occurs on the silica surface. ${ }^{43}$ Among the other oxygenated compounds, carboxylic acids are observed in greater amount with $\mathrm{NiO} /$ silica $(1.15 \%)$ than with $\mathrm{NiO} /$ alumina $(0.41 \%)$, in agreement with the better deoxygenation properties of this latter catalyst. In the same way, more alcohols are formed when pyrolyzing $\mathrm{OA}$ on $\mathrm{NiO} /$ silica $(5.12 \%)$ than on $\mathrm{NiO} /$ alumina $(2.91 \%)$. But a large majority of these alcohol and acid molecules are susceptible to transformation into unsaturated hydrocarbons when the experimental condition is slightly changed, DCO and dehydration being rather frequent reactions. A last point can be mentioned, dealing with the identification of some ketones in the condensable pyrolysate. In this case, the

Table 6. Area percentage of alkylbenzenes formed during the flash pyrolysis of pure OA, and OA adsorbed on both $\mathrm{NiO} / \mathrm{silica}$ and $\mathrm{NiO} / \mathrm{alumina}$ as a function of the number of $\mathrm{C}$ in the alkyl chain

\begin{tabular}{lccccccccccccc}
\hline $\begin{array}{l}\text { C number in the } \\
\text { alkyl chain }\end{array}$ & C0 & C1 & C2 & C3 & C4 & C5 & C6 & C7 & C8 & C9 & C10 & C11 $\begin{array}{c}\text { Total } \\
\text { area / \% }\end{array}$ \\
\hline $\mathrm{OA}$ & - & - & - & - & - & - & - & - & - & - & - & - \\
OA/NiO/silica & 1.3 & 0.8 & 0.3 & 0.3 & 0.3 & - & 0.2 & - & - & - & - & - & 3.2 \\
OA/NiO/alumina & 2.9 & 3.4 & 1.2 & 0.6 & 0.5 & 0.1 & 0.5 & 0.5 & 0.4 & 0.6 & - & 0.3 & 11.0 \\
\hline
\end{tabular}

Table 7. Distribution of 1-alkenes formed during the flash pyrolysis of oleic acid (OA) and OA adsorbed on both NiO/alumina and NiO/silica

\begin{tabular}{|c|c|c|c|c|c|c|c|c|c|c|c|c|c|c|c|c|}
\hline System & $\mathrm{C} 3$ & $\mathrm{C} 4$ & $\mathrm{C} 5$ & $\mathrm{C} 6$ & $\mathrm{C} 7$ & $\mathrm{C} 8$ & C9 & $\mathrm{C} 10$ & $\mathrm{C} 11$ & $\mathrm{C} 12$ & $\mathrm{C} 13$ & $\mathrm{C} 14$ & $\mathrm{C} 15$ & $\mathrm{C} 16$ & $\mathrm{C} 17$ & Total \\
\hline OA & 0.21 & - & 0.27 & 0.34 & 0.25 & 0.12 & 0.10 & 0.08 & 0.09 & 0.08 & - & 0.10 & 0.07 & 0.06 & 0.06 & 1.83 \\
\hline $\mathrm{OA} / \mathrm{NiO} /$ silica & - & - & 3.71 & 7.77 & 3.78 & 2.38 & 2.38 & 1.75 & 1.79 & 1.74 & 1.24 & 1.54 & 1.60 & 0.61 & 3.21 & 33.5 \\
\hline OA/NiO/alumina & - & 7.13 & - & 2.48 & 1.52 & 1.57 & - & 0.99 & 1.59 & 1.50 & 1.07 & 0.84 & 0.98 & 0.46 & 0.60 & 20.73 \\
\hline
\end{tabular}


amount of ketones is lower with $\mathrm{OA} / \mathrm{NiO} /$ silica $(0.27)$ than with $\mathrm{OA} / \mathrm{NiO} /$ alumina $(0.70)$. This is probably linked to the fact that ketones have been shown to be important intermediate species during the cracking of saturated fatty acids in the presence of activated alumina. ${ }^{19,20}$

The present results confirm that during the decomposition of oleic acid adsorbed on the catalysts, cooperative processes occur between the support surface and the active phase surface. On the one hand, the products are different from the products obtained during cracking without catalysts and therefore, the thermal decomposition has limited importance; on the other hand, both catalysts also generate not always similar products, indicating that the adsorption properties on both catalysts are different. Therefore, as was advocated in a preceding publication, it is confirmed that the present experimental conditions using flash pyrolysis of adsorbed species can be seen as a "pseudo" catalytic test, helping a description of the potential properties of a catalyst before its use in more classical flow or batch reactors. ${ }^{31}$

\section{Conclusions}

The flash pyrolysis of oleic acid adsorbed on supported nickel catalysts generates complete decomposition of the fatty acid whereas the pyrolysis without catalyst allowed a decomposition lower than $10 \%$. The products of pyrolysis with supported nickel catalysts were highly deoxygenated, and hydrocarbon content close to $80 \%$ was observed in both cases. The selectivity to hydrocarbons was different for both catalysts: an important amount of 1-alkenes was obtained with oleic acid adsorbed on $\mathrm{NiO} /$ silica, whereas $\mathrm{NiO} /$ alumina generated more alkene isomers, more polyunsaturated hydrocarbons and more aromatic compounds than $\mathrm{NiO} /$ silica. The differences of selectivity can be linked on one hand to hydrogen transfer occurring when alumina is used as support, and on the other hand to different adsorption modes of oleic acid on both catalysts, with the carboxylate species probably being more important with alumina support than with silica support. The flash pyrolysis of adsorbed fatty compounds can be proposed as a quick "pseudo" catalytic test to select catalysts before long term reactions are initiated.

\section{Acknowledgements}

Financial support from UFPE, FINEP, PETROBRAS, PRH28/ANP/PETROBRAS and RECAT (Rede Norte Nordeste de Catálise) are acknowledged. This work is centered on nickel catalyst properties, which was one of the elements extensively studied by Roberto F. Souza during his successful career.

\section{References}

1. Schuchardt, U.; Sercheli, R.; Vargas, R. M.; J. Braz. Chem. Soc. 1998, 9, 199.

2. Pinto, A. C.; Guariero, L. L. N.; Rezende, M. J. C.; Ribeiro, N. M.; Torres, E. A.; Lopes, W. A.; Pereira, P. A. P.; Andrade, J. B.; J. Braz. Chem. Soc. 2005, 16, 1313.

3. Ma, F.; Hanna, M. A.; Bioresour. Technol. 1999, 70, 1.

4. Maher, K. D.; Bressler, D. C.; Bioresour. Technol. 2007, 98, 2351.

5. Kubickova, I.; Kubicka, D.; Waste Biomass Valorization 2010 , 1, 293.

6. Fréty, R.; Rocha, M. G. C.; Brandao, S. T.; Pontes, L. A. M.; Padilha, J. F.; Borges, L. E. P.; Gonzalez, W. A.; J. Braz. Chem. Soc. 2011, 22, 1206.

7. Oliveira, E.; Quirino, R. L.; Suarez, P. A. Z.; Prada, A. G. S.; Thermochim. Acta 2006, 450, 87.

8. Mittelbach, M.; Gangl, S.; J. Am. Oil Chem. Soc. 2003, 80, 817.

9. Dunn, R. O.; Fuel Process. Technol. 2005, 86, 1071.

10. http://www.transdolomites.eu/wp-content/uploads/ENIEcofining-pdf.pdf accessed in November 2014.

11. Gusmao, J.; Brodzki, D.; Djega-Mariadassou, G.; Fréty, R.; Catal. Today 1989, 5, 533.

12. Kubicka, D.; Kaluza, L.; Appl. Catal., A 2010, 372, 199.

13. Kubicka, D.; Horacek, J.; Setnicka, M.; Bulanek, R.; Zukal, A.; Kubickova, I.; Appl. Catal., B 2014, 145, 101.

14. Wisniewski Jr., A.; Wiggers, V. R.; Simionatto, E. L.; Meier, H. F.; Barros, A. A. C.; Madureira, L. A. S.; Fuel 2010, 89, 563.

15. Lima, D. G.; Soares, V. C. D.; Ribeiro, E. B.; Carvalho, D. A.; Cardoso, E. C. V.; Rassi, F. C.; Mundim, K. C.; Rubim, J. C.; Suarez, P. A. Z.; J. Anal. Appl. Pyrolysis 2004, 71, 987.

16. Fortes, J. C. P.; Baugh, P. J.; J. Anal. Appl. Pyrolysis 2004, 72, 103.

17. Lappi, H.; Alen, R.; J. Anal. Appl. Pyrolysis 2009, 86, 274.

18. Prado, C. M. R.; Antoniosi, N. R.; J. Anal. Appl. Pyrolysis 2009, $86,338$.

19. Leung, A.; Boocock, D. G. B.; Konar, S. K.; Energy Fuels 1995, 9, 913.

20. Billaud, F.; Tran Minh, A. K.; Lozano, P.; Pioch, D.; J. Anal. Appl. Pyrolysis 2001, 58, 605.

21. Araujo, L. R. R.; Scofield, C. F.; Pastura, N. M. R.; Gonzalez, W. A.; Mat. Res. 2006, 9, 181.

22. Dupain, X.; Costa, D. J.; Schaverien, C. J.; Makkee, M.; Moulijn, J. A.; Appl. Catal., B 2007, 72, 44.

23. Maher, K. D.; Kirkwood, K. M.; Gray, M. R.; Bressler, D. C.; Ind. Eng. Chem. Res. 2008, 47, 5328.

24. Snare, M.; Kubickova, I.; Maki-Arvela, P.; Eranen, K.; Murzin, D. Y.; Ind. Eng. Chem. Res. 2006, 45, 5708.

25. Maki-Arvela, P.; Kubickova, I.; Snare, M.; Eranen, K.; Murzin, D. Y.; Energy Fuels 2007, 21, 30. 
26. Lestari, S.; Maki-Arvela, P.; Simakova, I.; Beltramini, J.; Lu, G. Q. M.; Murzin, D. Y.; Catal. Lett. 2009, 130, 48.

27. Dos Anjos, J. R. S.; Gonzalez, W. A.; Lam, Y. L.; Fréty, R.; Appl. Catal. 1983, 5, 299.

28. Reguera, F. M.; Araujo, L. R. R.; Picardo, M. C.; Bello, F. O.; Scofield, C. F.; Pastura, N. M. R.; Gonzalez, W. A.; Mat. Res. 2004, 7, 343.

29. Madsen, A. T.; Ahmed, E. H.; Christensen, C. H.; Fehrmann, R.; Riisager, A.; Fuel 2011, 90, 3433.

30. Asomaning, J.; Mussone, P.; Bressler, D. C.; J. Anal. Appl. Pyrolysis 2014, 105, 1.

31. Fréty, R.; Pacheco, J. G. A.; Santos, M. R.; Padilha, J. F.; Azevedo, A. F.; Brandao, S. T.; Pontes, L. A.; J. Anal. Appl. Pyrolysis 2014, 109, 56.

32. Elmasry, M. A. A.; Gaber, A.; Khater, E. M. H.; J. Therm. Anal. 1998, 52, 489.

33. Brockner, W.; Ehrhardt, C.; Gjikej, M.; Thermochim. Acta 2007, 456, 64.

34. Jasik, A.; Wojcieszak, R.; Monteverdi, S.; Ziolek, M.; Bettahar, M. M.; J. Mol. Catal. A: Chem. 2005, 242, 81.

35. Ewans, J. E.; Song, S.; Leon-Sucre, C. E.; Metall. Mater. Trans. B 1976, 7, 55.

36. Musić, S.; Filipović-Vinceković, N.; Sekovanić, L.; Braz. J. Chem. Eng. 2011, 28, 89.
37. Souza Santos, P.; Souza Santos, H.; Toledo, S. P.; Mat. Res. 2000, 3, 104.

38. Nazemi, M. K.; Sheibani, S.; Rashchi, F.; Gonzalez-DelaCruz, V. M.; Caballero, A.; Adv. Powder Technol. 2012, 23, 833.

39. Langford, J.; Wilson, A.; J. Appl. Crystallogr. 1978, 11, 102.

40. Rocha Filho, G. N.; Brodzki, D.; Djega-Mariadassou, G.; Fuel 1993, 72, 543.

41. http://www.uop.com/new-uopcepsa-detal-plus-processtechnology-for-the-production-of-linear-alkylbenzene-lab/ accessed in November 2014.

42. de Almeida, J. L. G.; Dufaux, M.; Ben Taarit, Y.; Naccache, C.; Appl. Catal., A 1994, 114, 141.

43. Hasegawa, M.; Low, M. J. D.; J. Colloid Interface Sci. 1969, 30,378 .

44. Wu, N.; Fu, L.; Su, M.; Aslam, M.; Wong, K. C.; Dravid, V. P.; Nano Lett. 2004, 4, 383.

45. Jian, P.; Wang, Q.; Zhu, C.; Xu, Y.; Appl. Catal., A 1992, 91, 125.

46. Tournayan, L.; Charcosset, H.; Fréty, R.; Trambouze, Y.; Ind. Chim. Belge 1973, 38, 496.
Submitted: August 15, 2014

Published online: November 14, 2014 